\title{
NCAA Division I Athlete STEM Graduates: Stereotypes, Microaggressions, Race, and Gender
}

\author{
Eddie Comeaux, Whitney Griffin, Patina Bachman \\ University of California Riverside
}

\author{
Jeff Porter \\ University of Michigan
}

\begin{abstract}
The purpose of this study was to explore how NCAA Division I athlete STEM graduates viewed their undergraduate experiences with members of the campus community such as academic advisors, other athletes, faculty, nonathlete students, and coaches. Using several interpretive frameworks, this study found that stereotypical assumptions, whether positive or negative, were conditional upon the athlete's gender. Moreover, male athletes reported feeling a level of acceptance from campus members, although this same experience was eventually interpreted as token or conditional acceptance, largely because they were subjected to salient athlete microaggressions and considered exceptional but not entirely accepted by the academic community. The study also discovered that athletes who pursued degrees in STEM fields engaged in in-group stereotyping of other athletes, and some were aware of the social significance of race and intersectional identities in shaping the quality of their college experiences. These findings have implications for faculty, student affairs professionals, and others who frequently interact with college athletes and are committed to creating more equitable educational environments.
\end{abstract}

Keywords: athletes, STEM, stereotypes, microaggressions, race, gender, critical race theory, intercollegiate athletics, hegemonic masculinity

Despite overall increases in college degree participation, racial and ethnic minoritized groups, such as Blacks, Hispanics, Native Americans, and Pacific Islanders, are largely underrepresented in science, technology, engineering, and math (STEM) degree programs compared with their overall presence in the U.S. population (National Science Board, 2015; National Science Foundation \& National Center for Science and Engineering Statistics, 2015). While precollege opportunity

Comeaux, Griffin, and Bachman are with the Graduate School of Education, University of California Riverside, Riverside, California. Porter is with the Dept. of Education, University of Michigan, Ann Arbor, Michigan. Address author correspondence to Eddie Comeaux at eddie.comeaux@ucr.edu. 
gaps (e.g., in math/science preparation) exist as barriers for many of these students, experiences in STEM higher education, such as lack of academic and social support, also contribute significantly to the low rates of STEM persistence among minoritized college students (National Academies, 2011). For example, many underrepresented STEM college students must overcome stereotype threat (Chang, Eagan, Lin, \& Hurtado, 2011), negative stigmas from participation in minority-focused programs (Hurtado, Cabrera, Lin, Arellano, \& Espinosa, 2009), and academic and social isolation (National Academies, 2011).

Students who make up other college subpopulations, such as college athletes, may experience similar challenges in pursuing STEM degrees in addition to encountering unique challenges stemming from their subpopulation membership. Such challenges - as well as those influenced by their sports obligations, like scheduling and limited access to STEM activities and resources - create barriers that result in far fewer college athletes pursuing STEM majors in comparison with other majors (Schneider, Ross, \& Fisher, 2010). With the increasing demand for STEM competency in postcollege careers and occupations (National Science Foundation, 2015), it is imperative for college athletes, like their nonathlete peers, to have STEM areas of study available as viable and supported degree options.

Theories suggest that factors like social and academic integration through nonsport-related extracurricular activities are critical to college athlete success (Comeaux \& Harrison, 2011). Research indicates that participation in extracurricular activities like undergraduate research, academic student organizations (e.g., professional societies or STEM-related clubs) and peer study groups increases the likelihood of STEM persistence among underrepresented students (Chang, Sharkness, Hurtado, \& Newman, 2014; Eagan et al., 2013; Herrera \& Hurtado, 2011). Yet accessing such critical experiences is often a major challenge for college athletes who pursue STEM degrees or STEM-related programs of study, as structural impediments (e.g., demanding sports schedules) can prevent them from participating in such high impact, educationally purposeful activities (Watt \& Moore, 2001). In addition to scheduling, research suggests that many college athletes may gravitate toward or are directed to pursue majors that allow greater flexibility in scheduling or that are perceived to present fewer academic challenges to their sports eligibility (Fountain \& Finley, 2011; Gurney \& Southall, 2013), such as those in the social sciences or communications - notably, fields other than STEM (Schneider et al., 2010). Such practices, whether inadvertent or intentional, further hinder college athletes' access to STEM degree pursuit. For college athletes, these challenges represent just some of the additional barriers to pursuing STEM majors or areas of study. ${ }^{1}$

With such different challenges in comparison with their nonathlete peers (Watt $\&$ Moore, 2001), college athletes constitute a unique minority subpopulation of college STEM students; however, there is a paucity of research addressing the specific and often complex challenges they and other subgroups of STEM students face. Therefore, the foremost question raised by existing research is how we can better understand STEM experiences of minority subgroups such as college athletes. By understanding the challenges of college athletes we may also lead the way to enhancing our understanding of how various factors compound to impact STEM degree persistence for other minority subgroups of college students.

With these issues in mind, we explored how National Collegiate Athletic Association (NCAA) Division I athlete STEM graduates viewed their undergraduate 
experiences with members of the campus community, including academic advisors, other athletes, faculty, nonathlete students, and coaches. We used the related literature on stereotypes and microaggressions as well as the interpretive frameworks of hegemonic masculinity and critical race theory to specifically understand and explain college athletes' experiences in STEM majors. Likewise we offered suggestions for future research and practice that may help to improve learning environments for athletes who pursue STEM degrees.

\section{Athlete Stereotypes, Microaggressions, Hegemonic Masculinity, and Critical Race Theory}

This literature review section is organized into four related areas. First we review relevant literature on stereotypes associated with Division I college athletes by race, gender, and the intersection of these two characteristics. In particular we examine a growing body of literature related to how faculty, students, and other members of the campus community view athletes in academic settings and the impacts of these views on their overall well-being. Next, we introduce and highlight the influence of athlete microaggressions targeted at this special population of students. The information in these two related areas provide a basis for concluding that college athletes are a nontraditional student group that encounter many environmental challenges while balancing both their athletic commitments and academic obligations. Third, we discuss the concept of hegemonic masculinity to explain the gendered character of the STEM field. Lastly, we discuss critical race theory (CRT) as a framework to understand and explain systems of oppression and marginalization that college athletes of color, namely Black athletes, encounter at predominately White institutions (PWIs).

\section{Athlete Stereotypes}

College sports provide athletes with access to higher education while enabling them to engage academically as well as to participate in competitive athletics at an amateur level. Although the allure of obtaining a higher education degree presents the idea of a fair exchange, it is well-documented that, among other impediments, many athletes at NCAA Division I schools encounter negative stereotypes too often linked to their intelligence (Benson, 2000; Clark \& Parette, 2002; Comeaux, 2011; Edwards, 1984; Engstrom, Sedlacek, \& McEwen, 1995; Sailes, 1993; Simons, Bosworth, Fujita, \& Jensen, 2007). For example, in a study that employed the Situational Attitude Scale, Comeaux (2011) discovered that faculty perceived Division I male athletes negatively in areas concerning intellectual abilities, special services such as an expanded tutorial program, and out-of-class achievements.

As well, Division I Black male athletes in particular experience some of the most detrimental and deeply-rooted racial stereotypes by members of the campus community (Edwards, 1984; Johnson, Hallinan, \& Westerfield, 1999; Sailes, 1993; Singer, 2005). For example, Sailes (1993) found that Division I White and male college students believed that African American athletes were not academically prepared to attend college, and were not as intelligent and did not receive grades as high as those received by White athletes. This finding is consistent with the literature 
on the unappealing "dumb jock" image, which suggests Black athletes have limited intellectual abilities, lack motivation, and do not perform well academically (Benson, 2000; Edwards, 1984; Harrison, 1998; Lapchick, 1996; Simons et al., 2007).

Furthermore, although the number of female college athlete participants continues to grow since Title IX of the Education Amendments of 1972, there is little extant research on the types and magnitude of attitudes held by members of the college community toward female athletes (e.g., Comeaux, 2011; Simons et al., 2007). In fact, in a study of faculty attitudes toward NCAA Division I athletes, Comeaux (2011) found that faculty held more negative toward male revenue and nonrevenue athletes than toward female athletes. Perhaps this is because female athletes exhibit academic success similar to that of their nonathletic peers, and considerably greater than that of their male counterparts (Simons, Van Rheenen, \& Covington, 1999). Conversely, female college athletes have been subjected to negative stereotypes, and as such those in certain sports have been viewed as less feminine than their female nonathlete peers by members of the campus community (Birrell \& Cole, 1994).

Relatedly, Black female college athletes have had to contend with such firmly held racial stereotypes as hypersexuality and masculinity (Liberti, 1999). The dual effects of racism and sexism on Black female athletes continue to exist at both historically Black and predominantly White institutions (Bruening, 2005; Bruening, Armstrong, \& Pastore, 2005; Corbett \& Johnson, 2000). For example, in a qualitative interview study, Bruening and colleagues (2005) examined the collective experiences of Division I African American female athletes at a large midwestern university. The researchers employed the ideological standpoint of Collins (1990) to understand the effects of intersectionality on the "silencing" of African American female athletes. The authors discovered that the mass media, coaches, athletic administrators, and other athletes played a role in virtually ignoring their experiences and concerns. As such, the concept of intersectionality revealed how challenges encountered by African American female athletes might differ in some cases from other women and their Black male counterparts. According to Davis (1995), "stereotypes also represent barriers to complete integration of this group [female student-athletes] into intercollegiate athletics" (p. 644), and they limit opportunities to maximize their learning in certain academic settings (Comeaux \& Harrison, 2011). In short, it appears that negative stereotypes are experienced to some degree by all college athletes within academic settings, regardless of their race, sport, gender, or the intersection of race and gender.

The threat of negative stereotypes can have pernicious effects on decisionmaking and behavior patterns for those who are targets (Steele, 2010). Stereotype threat emerges from "the immediate situational threat that derives from the broad dissemination of negative stereotypes about one's group - the threat of possibly being judged and treated stereotypically, or of possibly self-fulfilling such a stereotype" (Steele \& Aronson, 1995, p. 798). Researchers have proposed that in some academic situations, stereotypes about athletes distort perceptions of individual performance, and in other situations, just the mere salience of the stereotypes has the potential to undermine their best performance efforts in the classroom (Martin, Harrison, Stone, \& Lawrence, 2010). The mere possibility of being judged is enough to deter a student from raising a hand or distract them from contributing to a group discussion if they are triggered to become hyperaware of their performance. 
Strain on performance and mental functioning reflects the physiological effect of stereotype threat on cognition and affect. The brain's ability to make good decisions and perform complex tasks is compromised in the presence of a situational cue regarding a possible threat and bad consequences in the social environment. In turn, this process "diverts attention and mental capacity away from the task at hand, which worsens performance and general functioning, all of which further exacerbates anxiety, which further intensifies the vigilance for threat and the diversion of attention" (Steele, 2010, p. 126). The vicious cycle resembles an ouroboros of self-doubt. Stereotype threat can be juxtaposed with the literature on choking under pressure, which explores unwanted skill failure. In essence, negative thoughts and worries about a situation and its outcomes use the resources that were once solely available to devote to the demanding task at hand and, as a result, poor performance ensues (Beilock, Jellison, Rydell, McConnell, \& Carr, 2006). Furthermore, the pressure to perform at an expected level of excellence in a STEM field in addition to cognitive diminishment can lead to emotional anxieties about intellectual abilities. Stone, Lynch, Sjomeling, and Darley (1999) found that the people most negatively affected by the threat of conforming to a negative stereotype are those whose sense of self-worth is connected to the outcome of their performance in the stereotype threatened domain. In the current context, the threat of possibly being judged or treated stereotypically can significantly influence how an athlete thinks and acts about their fit within STEM fields.

\section{Athlete Microaggressions}

Similar to negative stereotypes, microaggressions can have a profound impact on athlete learning and personal development and their complete integration into the college environment. Psychiatrist Chester Pierce and colleagues (1978) defined microaggressions as "subtle, stunning, often automatic, and non-verbal exchanges which are 'put downs' of Blacks by offenders" (p. 66). These subtle and sometimes unconscious exchanges are in fact viewed by offenders as harmless-even complimentary-although evidence reveals they can cause psychological distress and evoke stereotypes associated with one's intellectual ability (Constantine \& Sue, 2007; Solorzano, 1998; Solorzano, Ceja, \& Yosso, 2000).

Drawing from the work of Pierce and colleagues (1978), Comeaux (2012) employed the term athlete microaggressions to describe "subtle or overt, verbal or nonverbal exchanges (whether intentional or unintentional) which communicate negative and demeaning messages" toward college athletes, regardless of race, gender, or type of sport" (p. 191). The following is an example of an athlete microaggression described by an athlete in Comeaux (2012): "The professor stood up asking how many student-athletes are in class. When no one raised their hand, he said 'good, I don't have to slow down then'" (p. 193). Comeaux introduced the concept of athlete microaggressions as a way to label and validate the insensitive and demeaning behaviors directed at college athletes that might otherwise go unnoticed. It is also important to document and classify athlete microaggressions so that responsive intervention strategies can be more closely targeted. 


\section{Hegemonic Hegemony}

To understand the gendered character of college athletes who pursue STEM degrees, we employed the concept of hegemonic masculinity as an interpretive framework. This concept first emerged from the work of Kessler and colleagues (1982) on social inequality in Australian high schools, and eventually was applied to discussions about notions of masculinity and gender construction (see Connell, 1982; Connell, Ashenden, Kessler, \& Dowsett, 1982). Hegemonic masculinity "refers to a particular idealized image of masculinity in relation to which images of femininity and other masculinities are marginalized and subordinated" (Barrett, 1996, p. 130). The emphasis on hegemonic masculinity provides a way to explore gendered issues in a particular cultural or societal context. In contemporary Western societies, the hegemonic masculine image (e.g., toughness, violence and aggression, emotional restraint, competitiveness, dominance over women and other subordinate or marginalized groups) is generally associated with power, control, and privilege. As such, these characteristics are equated with a small, elite group of men. In contrast, the idealized image of women generally portrays them as subordinate, with a lower hierarchical positioning or social status (Connell \& Messerschmidt, 2005; Whisenant, Pedersen, \& Obenour, 2002). Whisenant and colleagues (2002) concluded that, in this context, "the voicelessness of women and other subordinate groups is explained away as commonsense and the natural order of things" (p. 486).

STEM degree programs are an arena in which hegemonic masculinity is evident (Page, Bailey, \& Van Delinder, 2009). In the academy, there is the perpetuation of implicit and explicit institutional structures and hegemonic practices that maintain men's power and privilege over women (Connell \& Messerschmidt, 2005). Hegemonic practices tend to reinforce the status quo as well as genderSTEM stereotypes that contribute to the gender disparities in students who pursue STEM degrees or STEM-related programs of study. For example, Moss-Racusin, Dovidio, Brescoll, and Graham (2012) found that science faculty members were more likely to offer career mentoring and job recommendations to male than female students. The authors also discovered that both male and female faculty viewed female students as less competent than their male counterparts. In addition, stereotypes linking men and masculine traits or the hegemonic masculine image, such as independence, in STEM fields are widespread (Cheryan, Plaut, Davies, \& Steele, 2009). In short, while hegemonic power has been challenged by subordinate groups and others, gender inequalities remain a significant issue in the STEM field as a whole.

The concept of hegemonic masculinity serves as a useful tool for analyzing and explaining athletes' thinking about their STEM experiences. In particular, because gendered issues, in their microlevel forms, are deeply embedded in western societies (Connell, 1987, 1995), they are likely to exist in the perceptions, attitudes, beliefs, assumptions, discourses, practices, and structures of a college or university environment. A hegemonic masculinity conceptual framework helps to explain and operationalize the role of gender in discourses on STEM athletes and to identify and analyze how prevailing notions of gender construction might affect female STEM athletes in a male-dominated arena. 


\section{Critical Race Theory}

To understand Black college athletes' perceptions of members of the campus community, the current study employed a critical race theory (CRT) interpretive framework. CRT emerged in the mid-1970s primarily from criticisms of the critical legal studies movement. Along with the foundational writings of W.E.B. Du Bois $(1903,1935)$, and the work of progressive legal scholars such as Derrick Bell (1987, 1992), Alan Freeman (1978), Richard Delgado (1984), and Kimberlé Crenshaw $(1991,1997)$, it attempted to foreground and account for the role of race and racism and to address social justice and the ways in which the judicial system has legitimized and legislated racial inequalities in the U.S. While CRT gained significant traction in legal studies, it has also influenced a great number of scholars in various disciplines to study the relationship between race, racism, and power (Ladson-Billings, 1998; Ladson-Billings \& Tate, 1995; Solorzano, 1998).

Critical race scholars have developed several tenets that describe CRT's theoretical role in education: (a) the centrality of race and racism and their intersection with other forms of oppression (e.g., class, gender, and sexual orientation); (b) the challenge to Eurocentric epistemology and traditional claims that institutions make toward objectivity, knowledge, race neutrality, and equal opportunity in the education system; (c) the legitimacy of experiential knowledge; (d) the commitment to social justice and transformative response to racial, gender, and class oppression; and (e) the transdisciplinary perspective from the fields of ethnic studies, women's studies, sociology, history, and law, among others (Crenshaw, 1991; Delgado, 1984; Ladson-Billings, 1998; Matsuda, Lawrence, Delgado, \& Crenshaw, 1993; Solorzano \& Yosso, 2001). These tenets represent a collective challenge to existing dominant ideologies and methods of conducting research on race, racism, and inequality in political institutions such as colleges and universities.

Essentially, CRT scholars view race as both a social construction and a powerful reality that is intimately ingrained in U.S. society (Ladson-Billings \& Tate, 1995). Race continues to be deeply problematic, and race relations are used to continually sustain the White hegemony in the U.S. This hegemony is supported by racial ideology that currently operates in a subtler manner than previous race segregation. Referring to dominant racial ideology, CRT scholars claim that these perspectives and ideas serve to advance the interests of people with power and influence while marginalizing nondominant groups (Ladson-Billings \& Tate, 1995). In this study, a CRT interpretive framework helps to explain and operationalize the role of race and racism (and other forms of oppression) in discourses on Black college athletes and members of the campus community. Likewise, CRT helps to identify, analyze, and transform how prevailing notions of racial coding might affect Black athletes' perceptions of the campus community and their experiences in STEM academic settings.

The aforementioned conceptual frameworks allowed us to examine athletes' views of their self-worth in the two highly demanding domains of STEM and elite sports. These frameworks informed our understanding of how athletes perceive their experiences with academic advisors, teammates, faculty, other students, and coaches. To this end, this study sought to answer to the following research question:

(1) How do Division I athlete STEM graduates perceive their undergraduate experiences with members of the campus community (i.e., academic advisors, other athletes, faculty, nonathlete students, and coaches)? 
By answering this question, committed higher education professionals and administrators can advance their understanding of STEM athletes' campus experiences to develop new cognitive schemata as well as fresh and imaginative programs that facilitate athletes' academic success and school-to-career transitions.

\section{Methods}

\section{Participants}

This study was performed with graduates of two Division I research-intensive, public institutions in the western and midwest sections of the U.S. We conducted 17 interviews with nine former athletes in the revenue-generating sports of football and men's basketball and eight in nonrevenue sports. Six athletes were female, and 11 were male; 13 self-identified as African American, two as White, and two as Hispanic (Latino). A purposeful sample was drawn from a population of STEM athlete graduates accessed through each university's Student Data Management System. Student academic information (e.g., cumulative GPA, units earned, enrollments, race/ethnicity, gender, etc.) allowed us to identify participants who met the selection criteria. We employed purposive sampling methods to identify STEM college athlete graduates (Patton, 2002), ensuring our participants were qualified to address the research question.

To be included in the study, participants had to have been: (a) partial or full athletic scholarship athletes; (b) freshman athletes between the years 2000 and 2008; and (c) STEM majors. Both university sites boasted graduation rates higher than the national average for athletes and the general student population. The academic support available to participants at the time they were students included advising, career development, tutorial programs, and learning specialists.

\section{Data Collection}

Following university institutional review board approval, data collection consisted of in-depth semistructured interviews, which is consistent with qualitative field method research (Burgess, 1984; Maxwell, 2005). The interview protocol was developed on the basis of a review of the literature on underrepresented STEM students. The protocol was not prescriptive, which allowed us flexibility to probe areas of interest associated with the broader goals of the study. The interview guide contained questions on goal orientations; types, frequency, and quality of STEM-related activities; types of social and academic experiences before and during college; challenges, costs, and aids to STEM persistence; experiences with faculty, department advisors, athletic advisors, other athletes, nonathlete students, and coaches related to academics. For example, we asked such questions as: "What were campus members' (e.g., STEM faculty, non-athletes peers, other athletes, advisors, coaches) expectations of you as a STEM student and athlete?," "did anyone or anything (e.g., coaches, faculty, stereotypes) deter you from persisting as a STEM college athlete along the way?," "what were some challenges you faced as a college athlete majoring in a STEM field?," "were professors or your non-athlete students ever surprised at a high grade you received in class (because you're an athlete)?," Each interview for this study lasted approximately 45 minutes. 
Before the actual interviews, pilot interviews were conducted with college athlete participants to improve the data collection process. The pilot interviews allowed us to get a better sense of the interview length, to make necessary modifications and clarifications to some interview questions, and to add follow-up questions. It is worthwhile to note that the pilot data were not reported in the final study.

\section{Data Analysis}

Each interview transcript was reviewed for accuracy by the research participants to ensure trustworthiness of the data (Shenton, 2004) and, as such, all participants agreed that the transcriptions were an accurate depiction of their experiences. Then, all interview data were analyzed through open and axial coding to identify emerging patterns and themes (Strauss \& Corbin, 1990). These processes involved reviewing, comparing, labeling, and categorizing the data, and the constant comparative method was used to examine similarities and differences and to draw new meaning (Strauss \& Corbin, 1990). This systematic approach meant that during the open coding process two of the study researchers read and reread participants' responses to get a holistic picture of their answers and independently identify possible patterns and raw data themes. Specifically, initial reflections and comments associated with each participant's responses were written in the margins of the transcripts, and key words and raw data themes were documented to capture the basis of the emerging analysis. During this process, the researchers regularly revisited the transcripts to ensure that the raw data themes reflected participants' accounts. The researchers also compared and contrasted their interpretations in the first order codes until they achieved consensus and were satisfied with the data categorizations. Then, during axial coding, the researchers organized open coding categories into smaller related clusters and identified relationships among codes. At this stage, the researchers discussed axial codes and collectively identified and interpreted major themes, locating commonalities and identifying support for these themes among the responses and across transcripts (Strauss \& Corbin, 1990).

To account for potential biases in analysis, the major themes were discussed with an independent researcher at several points. The independent researcher, a sociologist who had more than 20 years of experience in research and practice with college athletes as well as students of color, was involved only with the data analysis portion of the project. During this process, the independent researcher provided several recommendations for revising and clarifying some of the themes. After ongoing discussions between the primary researchers and independent researcher, collective agreement was reached on the final themes (Glaser \& Strauss, 1967). The aforementioned interpretive frameworks were used to make sense of the undergraduate experiences of STEM athlete graduates from these data.

\section{Results}

We identified four major themes in the STEM athlete participants' views concerning their experiences with campus members. In this section, these interrelated themes are illustrated with examples from participant responses. Certain identifying information is excluded from the quotations to preserve anonymity. In addition, 
pseudonyms are used for all participants to maintain their anonymity and to differentiate participants who are in the same sport; and themes are presented in order of saliency.

\section{Female Aggression vs. Male Acceptance}

Gender differences were noteworthy in this study. The way athlete participants experienced stereotypes was influenced by the perception of their gender in their interactions with faculty members and peers. For example, Sheri, a female volleyball player, expressed a very common sentiment among participants:

Yeah, there were a lot of stereotypes, especially in engineering. There were a lot of professors I really had to try and show them...especially for the ones that I could tell they stereotyped towards me. Being a female and an athlete, kind of seeing like I was casually slipping on by. I had to start being a little more aggressive, but the stereotypes definitely do exist.

Michelle, a female track athlete, echoed this comment: "Either you [are] having to be, like, the more aggressive one because you don't have that much time to deal with crap, you know? That you have to do most of the work yourself. Or you end up getting people who, they, like, don't really include you." Likewise, Sonia, a female track athlete, believed there was hostility toward athletes from members of the campus community: "It was just like, if people knew we were athletes...it's like they didn't even want to answer [our questions]. Knowing that they probably knew the answer...I don't feel like anyone liked athletes."

By contrast, the male athlete participants in this study experienced different treatment that included some level of acceptance by campus members. For example, Chris, a male track athlete, described his STEM peers' views of him in academic settings: "They thought I was cool. I was an athlete. And I mean, for the most part the people that I met that were non-STEM majors-You know, there's always that respect for being in engineering or in one of those really tough majors." In a similar light, Mike, a football athlete, commented: "You know, there's always the whole dumb jock thing, but with me they took it the opposite. Everyone thought I was a genius because... So they expected you to be the real smart guy." Jay, a male basketball player, likened his experience to the halo effect:

I think I get that effect because the degree which I was pursuing was automatically assumed by others, like, you're super smart. You're an engineer? Playing basketball? Oh, yeah. You're smart. I never once said, I never once heard anyone even mention or rumors mention[ed] towards me. "Oh, he's [a] dumb athlete. He's going to get bad grades. We need to help him out more. So, I think I understand where you're coming from. I think that I was an anomaly in that aspect.

When asked how he balanced academics and athletics, Pete, a male soccer player, responded: For me personally, [coaches] were always very receptive, just 'cause either it was my attitude or just the way I was, held myself. Whatever it was, they were very supportive of it and then, I don't know, I guess that helped a lot. Just the way my personality was, it helped a lot. 


\section{Academic Performance as Spectacle}

A majority of the male STEM athlete participants in this study felt that their strong performance in the classroom was viewed as uncommon, rather than expected. Participants noted the shock and amazement of their professors and peers at their intellectual contributions and grades. For example, Ron, a male football player, commented:

But when you walk into a meeting and the first thing that they [professors] say is, "I assume you don't understand this and that," before you even ask the question. Like, no, that's not what I came in here for; actually I do. And then you'd have to sit down and then, you know, "Oh, my God! You, oh, you're different!" or "Oh, my God. Yeah, you're really, really bright.”. .. And this is just the basic stuff of the course and you're like, "Um, okay. Thanks, I guess. But why is this such like a, why am I such a spectacle to you? Isn't everybody supposed to understand this stuff?". . . I kind of took it as kind of insulting. Like, why, I mean, why is it so, why's it so impressive for me to know this stuff, when this is stuff that you're supposed to, expected to be, to know?

Similar to other male participants, Pete, a soccer player, described his peers' views of his role as student and athlete in a STEM major:

I think my peers were surprised....I don't know if it's a norm that they think student athletes get good grades because they're athletes, or they think student athletes are not smart, or I don't know. But whenever I got good grades, some of the students or my peers were amazed, I guess."

Bryan, a male basketball player, expressed a similar sentiment:

It did surprise and shock them. I can remember professors reacting. I can remember students reacting as well...Honestly, it can be a little distracting, because when you're supposed to be doing group work the conversation comes up about the game last night or the game that's coming up. Things like that.

And Ryan, a football player, noted how he attempted to overcome the notion that he was inferior academically:

I guess one way that I tried to work around that was that I made sure that I was one of the more vocal leaders in the group so that I could set the standard in the beginning that I wasn't a dumb jock that didn't deserve to be in school.

\section{In-Group Negative Stereotyping}

Several athlete participants recognized their role in perpetuating stereotypes against other athletes, even though they were aware of their prejudices. Others consciously enacted certain stereotypes. Rachelle, a female track athlete, for example, expressed a very common sentiment when she described her attitude toward other athletes:

As an athlete, I stereotyped other athletes all the time....I would know personally some other athletes just from, like, hanging out with them, seeing them in the weight room, just like when you interact with each other and you're like, 
"Yeah I definitely don't want to be in a group project with you." [Laughter] So you just know. Because there are definitely some athletes that like ride to coattails, and then there are other athletes that don't. So there's both.

In a similar light, Marquis, a football player, noted:

Even I think that when I see football players that got good grades, that's the first thing I think, is that they must have had help. Maybe they really are smart. Maybe they did really work hard. It is a stereotype that a lot of athletes aren't very smart and stereotypes are based on fact most of the time. Yeah, I encountered that.

Sean, a football player, described how athletes, at times, associate with highachieving students to accomplish some level of academic success with minimal effort in the classroom:

There were times where you know, athletes try to find study groups because you want to find the group where the person is going to, like it's just a group assignment, the people who are going to do the bulk of it so that you can just kind of skate by on the coattails. I'm not going to lie, I did that occasionally. So, that does happen from time to time.

Another example is captured in the following quote from Renee, a female track athlete: "You know a lot of these basketball players, too- they don't even know what is going on. They are not even all that intelligent based on their background, you know?"

\section{Direct Reference to Racial Identity}

Although most athlete participants did not spontaneously discuss race in relation to their experience with members of the campus community in academic settings, a small portion did. For example, Sonia, a female track athlete, described the guidance she received from her academic advisor:

They just weren't listening, they don't listen. I don't know what to-again, I don't know if it is because I'm a Black female, because I went in there. Sometimes, you know, people guide you based on how you look.

Another example is captured in the following quote by Ron, a football player:

So as soon as I walked in, you know, with just coming out of morning workouts, I probably wasn't looking the peppiest at the time....And my professor actually looked up at me, and he was like, "Hey, can I... are you sure you're in the right place?" Like, “Can I help you get where you're going?' I'm like, “Oh my God. I'm not...you really think I'm not supposed to be in this class? Like, for real?" And I didn't make a big deal out of it. I was like, "Oh, so is this Info 343? Web Development?" He's like, “Oh yeah. I'm Professor ×." But it wasn't anything hateful that he said. It was just the fact that he really couldn't process this Black athlete walking into the room was going to be a part of this web programming class. And it just seemed like it was a foreign concept to him." 
Similarly, when asked about her strong academic performance and how she was viewed by classroom peers, Michelle, a female track athlete, commented, "I'm sure they were surprised. I think it was probably mostly related to the totality [of] my identity, including race and gender, that drew as much as the surprise, but also aspects of being an athlete."

\section{Discussion}

This study explored how Division I athlete STEM graduates viewed their undergraduate experiences with members of the campus community (i.e., academic advisors, teammates, faculty, other students) to gain insight into contextual factors, such as stereotypes and microaggressions, that influenced the quality of their college experiences while participating in a demanding sport. Scholars remind us that it is important to document not only the voices of students, but also the subtle forms of inequality, discrimination, sexism, and racism that have the potential to affect critical aspects of their quality of life, including mental and physical health (Constantine \& Sue, 2007; Solorzano, 1998; Steele, 2010), trust in internal stakeholders, and overall sense of belonging in campus learning communities (Smith, Allen, \& Danley, 2007).

Reports from college athlete participants in this study revealed there were gender differences in their experiences with members of the campus community. Some female athletes reported being aware of gender stereotypes and feeling pressured to be "more aggressive," overperform, or to prove their intelligence in academic settings. For some participants in the study, overperforming was a way "to try and show" professors that they did not fit the prescribed stereotype and that they were capable of being high-achievers in the classroom. While there is the added layer of being a female athlete in a STEM field and likely being perceived as less capable academically-as evidenced by participant responses in this study-this finding is consistent with other studies on nonathlete females in male-dominant STEM classrooms (Espinosa, 2011; Foschi, 2000; Moss-Racusin, Dovidio, Brescoll, Graham, \& Handelsman, 2012; Sax et al., 2016; Settles, Cortina, Malley, \& Stewart, 2006).

Looking deeper through a hegemonic masculinity interpretive framework, this finding suggests that hegemonic masculinity can be openly or subtly performed by men or women (Connell \& Messerschmidt, 2005). For some female STEM participants in this study who mentioned being "more aggressive" in classroom settings, it appears they tried not to perform and validate hegemonic masculinity, particularly when the "perceiver" (e.g., professors, students) viewed them as the socially constructed, conventional impression of a female category. In doing so, perhaps female STEM participants were rejecting an alternative or more comfortable form of expression to gain acceptance and some level of success in a hyper-masculine culture. Nonetheless, many organizations, including colleges and universities, value the hegemonic masculinity, and men and women who do not perform and validate hegemonic masculinity are subjected to various forms of discrimination and oppression in certain environments (Gardiner, 2004; Plummer, 2004).

Thus, the structures and hegemonic practices of undergraduate STEM programs work to perpetuate and maintain the inequality, unfair treatment and exclusion experienced by some female STEM athletes. It is also important to note that "these 
constructions are organized in hierarchies and exclusions and allow the formation of hegemonic representations of femininity and masculinity in certain contexts" (Carrieri et al., 2013, p. 286). We refer the reader to other works for a more thorough explanation of hegemonic representations of femininity and masculinity in different contexts (e.g., Gardiner, 2004; Gilligan, 1982; Mavin, Bryans, \& Waring, 2004; Plummer, 2004; Scott, 1986).

Furthermore, some female STEM athlete participants described the academic environments that they encountered as hostile and discouraging, a bias pattern that lends support to previous works on nonathlete students (Cole \& Espinoza, 2008; Espinosa, 2011; Foor \& Walden, 2009). To be clear, it is well documented that hostile campus environments can impact student learning and personal well-being (Comeaux \& Harrison, 2011; Martin et al., 2010; Steele, 2010; Steele \& Aronson, 1995).

Many male participants, on the other hand, described being complimented by peers for their combined athletic and intellectual prowess. This finding is encouraging, considering that the athlete participants' peers in this study seemed to feel some level of acceptance in certain learning environments. Nevertheless, the views of members of the campus community toward college athletes generally must be placed within the larger context of higher education learning communities and the growing body of related literature on campus members' views of college athletes.

Research indicates that faculty and nonathlete students have more negative perceptions of the academic abilities of male and female athletes than they do of their nonathlete peers (Comeaux, 2011; Engstrom et al., 1995; Sailes, 1993; Simons et al., 2007). In light of this research, it appears that male STEM athletes in this study were exceptions to the rule and given some level of acceptance or feelings of inclusion, and as such did not fall within dominant, negative views of athletes regarding their academic abilities (Benson, 2000). And, these same athlete participants were aware of their position of being deviations from the norm as Mike noted: "there's always the whole dumb jock thing, but with me they took it the opposite" and "I think that I was an anomaly in that aspect."

As we probed further, the male athlete participants' aforementioned level of acceptance by their peers appears to be token or conditional acceptance, as evidenced by how they were positively stereotyped or described as "super smart" and "genius," and their high academic achievement was seen as exceptional rather than the norm. In this sense, the positive stereotypes of male athletes in this study actually perpetuated their disadvantaged status in these academic environments. Moreover, token or conditional acceptance would suggest these male athletes were largely viewed by their peers through a deficit cognitive frame-as inferior intellectually or as peripheral members of the academic community-rather than as equals. Put another way, these athletes were exceptional but not entirely accepted by the academic community. This "othering practice," which is "a process that identifies those that are thought to be different from oneself or the mainstream, and it can reinforce and reproduce positions of domination and subordination," was painfully apparent for male athletes in this study (Johnson et al., 2004, p. 253).

Relatedly, some male athletes in this study reported that their professors and nonathlete peers harbored negative assumptions that called into question their intelligence, which, in these noted cases, can be interpreted as athlete microaggressions (Comeaux, 2012). For example, Pete's comments about his peers being 
surprised and shocked about his high academic achievement was rooted in the assumption that athletes generally lack the intellectual capacity to perform at a high level academically. This athlete microaggression is similar to what Sue and colleagues (2007) interpreted as a microassault, and is likewise consistent with the literature on the "dumb jock" stereotype, which argues that college athletes are generally viewed as inferior academically (Edwards, 1984; Sailes, 1993; Simons et al., 2007). It is plausible that the reported negative stereotypes of athletes existed because these members of the campus community were conforming to stereotypes shared by a large segment of the academic community and/or they had limited meaningful interactions with athletes, so there was a tendency for these campus members to have extreme evaluations of them (Jussim, Coleman, $\&$ Lerch, 1987). While the male participants in this study reported microaggressive acts, it is worthwhile to note that female athletes indeed did not describe any such acts. Perhaps this is because female athletes perform considerably better in the classroom than their male counterparts (Simons, Van Rheenen, \& Covington, 1999).

Some high achieving STEM athletes in this study reported in-group stereotyping that can perpetuate negative stereotypes about college athletes. Persistent stereotypes also have the potential to undermine athletes' best efforts in the classroom or even lead to self-fulfilling prophecies as faculty, peers, and the athletes themselves assume low academic performance (Steele, 1992; Stone et al., 1999). Rather than questioning the legitimacy of the system that produces and reproduces negative stereotypes of athletes about their intellectual abilities, it appears that the athlete participants in this study consciously subscribed to constructed beliefs and attitudes about other athletes on the basis of preconceived notions and intuitions, rather than on the basis of evidence. For example, Renee's deficit-oriented comment that basketball players "are not even all that intelligent based on their background" is not factual accurate (see Martin et al., 2010; Oseguera, 2010). This comment and other related beliefs, which are likely shared with other members of the campus community, only work to sustain oppressive environments and disadvantage all athletes. It is possible that some athletes in this study negatively stereotyped other athletes as a way to maintain their own self-esteem or to achieve psychological gain by comparing themselves favorably to other athletes, to defend athletes' actions when they did not perform well in the classroom, and/or because they subscribed to stereotypes uniformly shared by members of the academic community (Jussim et al., 1987; Tajfel, 1978).

Lastly, a small portion of the participants attributed negative stereotyping and discriminatory practices to their multiple identities (e.g., race, gender, athlete). Noteworthy is that these participants appeared to be keenly aware of the social significance of race and intersectional identities in academic settings as well as the powerful realities intimately ingrained in U.S. society (Crenshaw, 1991; Ladson-Billings, 1998). For example, Michelle, a track athlete, noted that her race and gender were likely connected to negative stigmas imposed on her by campus members. From a critical race theory (CRT) standpoint, Michelle did not appear to subscribe to a colorblind ideology; instead, she seemed to recognize her intersectional identities as a woman and of color (and athlete), and how she could be marginalized within multiple identities (Crenshaw, 1991). Put another way, Michelle appeared to know both who she was as a Black female athlete as 
well as the thoughts and actions of her peers in academic settings based upon those multiple identities. This finding corroborates previous research (Bruening et al., 2005) that intersectional identities matter and that Black female athletes can be subjected to oppressive and toxic academic environments. By understanding intersectionality - a tool of CRT - it helps to advance our understanding of how dominant racial ideologies and their intersection with gender work to maintain inequalities for Black female students attending PWIs.

\section{Limitations}

Like most studies, the current study is not without limitations. First, the participants were first year college athletes between the years 2000 and 2008, and as such their different sociopolitical environments and age differences to some degree might have affected their undergraduate experience. In addition, in retrospective studies, participants' might suffer from selective memory or incomplete information because they are asked to recall situations that occurred in some cases several years before the actual interview. Generalizations from this study thus should be made with caution and consideration of these limitations.

\section{Implications for Research and Practice}

These findings advance our understanding of how Division I athlete STEM graduates viewed their undergraduate experiences with members of the campus community. The study documented the college experiences of STEM athletes in academic settings, so that responsive intervention strategies can be more closely targeted throughout the so-called STEM pipeline. Employing interpretive frameworks, we found that stereotypes were influenced by the perception of athletes' gender, and the concept of hegemonic masculinity as a performed practice in undergraduate STEM programs offered insight into these gender differences. In addition, male athletes reported feeling a level of acceptance from members of the campus, although this was conditional and eventually interpreted as token or conditional acceptance, because athlete participants were subjected to athlete microaggressions as well as viewed through a deficit-minded lens by professors and nonathlete students during their undergraduate studies. We also discovered that athletes who pursued degrees in STEM fields engaged in in-group stereotyping of other athletes, and that some STEM athlete participants were aware of the social significance of race and intersectional identities in shaping the quality of their college experience.

Results of this study demonstrate that professors and their nonathlete peers held stereotypes as well as microaggressive assumptions about STEM athletes' intellectual abilities. It is imperative that internal athletic stakeholders such as academic advisors/counselors, faculty members, learning specialists, and coaches understand the campus climate that STEM college athletes are asked to succeed within; they must work closely with them upon entrance to college, identifying factors that may impede or facilitate their academic talent development and/or selfidentity. But awareness and understanding among internal athletic stakeholders is not enough. It is critical that this awareness and understanding lead to actions that create optimal learning environments for STEM athletes (Comeaux, 2015b) and that disrupt a seemingly unregulated multibillion athletics enterprise that too often 
does not have the best interests of all college athletes (see Edwards, 1969; National College Players Association, 2013; Oriard, 2003).

The present study confirms that gender equity remains an ongoing issue in STEM degree programs. One approach to improving gender equity in the STEM field is through mentoring programs (Boyle \& Boice, 1998). It would be wise for science faculty and STEM program leaders to develop optimal mentoring programs to improve the climate in academic settings and to enhance the academic talent development of both men and women STEM participants. Without such action, it will be challenging for STEM athletes, particularly women, to survive and even develop within a dominant masculine culture. As well, there is a need to question the legitimacy of the systems that produces and reproduces gender inequalities in undergraduate STEM program as well as in larger society. Rather than believing that men and women should conform to dominant masculine cultures, it would be wise for institutions to more closely explore how their educational environments and classroom practices facilitate or impede desirable experiences for students completing STEM degrees. A deeper understanding of these elements through institutional self-examination will help educators to make precise observations about and recommendations for more inclusive learning environments.

Considering that we know science faculty members play an important role in creating a healthy classroom culture, it is important that future research employ interviews and other methods to reveal how their perceptions and attitudes might impede and/or advance male and female athletes who pursued degrees in STEM fields. Further, since this study was conducted at two institutions, additional studies with a diverse set of universities and colleges would confirm whether the present results are robust.

This study also further documented everyday athlete microaggressions in classroom settings. Athlete microaggressions are likely to go unnoticed by perpetrators (e.g., professors and nonathlete students) and they might view them as harmless - even complimentary - although evidence reveals they cause psychological distress (Constantine \& Sue, 2007). Comeaux (2012) concluded "the label athlete microaggressions should serve as a marker-a call for further understanding, acknowledgement, and confirmation of the validity of subtle or overt forms of inequality and discrimination toward college student-athletes" (p. 196). Internal athletic stakeholders, namely academic advisors/counselors, learning specialists, coaches, faculty, nonathlete students, and athletes themselves, are encouraged to use the term athlete microaggressions as a common language to classify and validate the insensitive, demeaning, and sometimes subtle behaviors by members of the campus community that might otherwise go unnoticed.

Results of this study also reveal the persistence of in-group stereotyping among athletes associated with their intellectual abilities. In-group stereotyping among athletes only serves to perpetuate a negative dominant narrative about their intellectual abilities. This in-group stereotyping also can undermine athletes' performance in the classroom or even lead to self-fulfilling prophecies (Comeaux, 2012). It is imperative that athletic stakeholders create ideal conditions for quality interaction as well as open and honest dialogue among athletes to unpack constructed beliefs and attitudes, whether positive or negative, that they have about each other to change material reality. As such, initiatives facilitated 
by student affairs professionals and faculty to create optimal conditions for athletes to communicate meaningfully across race, gender, and type of sport could include workshops and structured leadership training during the off-season, and meaningful exchanges that challenge students to think about their own and others' worldviews through purposeful team activities and comprehensive educational programs.

Furthermore, results of the current study show a small portion of athlete participants acknowledged their racial or intersectional identities and their concerns with campus members in academic settings. Racial (and gendered) stereotypes are often subtle and very powerful, and as such even a relatively small number of athlete participants who have negative experience can be damaging. It is conceivable, for example, that these same participants may share their stories with teammates and other athletes who might ascertain that are viewed and feel similarly in academic settings. As a result, the concerns reported by college athletes in this study can take on greater significance than one might think. College athletes might interpret their campus climate as racial hostile, which, in turn, could influence their engagement in learning communities (Comeaux \& Harrison, 2011). With this in mind, it would be prudent for future studies not only to document how STEM college athletes manage and overcome discriminatory acts about their intersectional identities, but also how they develop effective coping strategies to protect themselves from a hostile campus climate.

Looking deeper through a CRT analytical lens, we see the social significance of race and how it has continued to affect the quality of educational experiences for athletes of color. It is clear that interventions designed to combat racial inequalities and address the social significance of race and subtle racism in the lives of Black students and other students of color is imperative. While some faculty, nonathlete peers, and others within the academic community may not be consciously aware that they harbor prejudicial attitudes toward athletes, it would be instructive for student affairs professionals to work closely with CRT scholars and other stakeholders who are racially literate to initiate and design professional development trainings and workshops that include sessions on specific cultural groups, including Black male and female athletes, who are prone to prejudice and discrimination from the campus community. An interactive and experiential session on racial stereotypes and microaggressions, for example, would facilitate intergroup dialogue and foster cross-cultural understanding of the types of conscious and unconscious prejudices and discriminatory attitudes directed toward certain students. As an initial step to overcoming racial biases and prejudices, it would also be prudent for session participants to examine their own racial identities and their feelings toward other racial groups. These efforts may lead to racial self-awareness as well as racial literacy, and could ultimately contribute to the creation of more supportive and less alienating environments for college athletes.

\section{Note}

1.We refer the reader to other works for more thorough explanations of how external forces shape the quality of experiences for athletes (e.g., Clotfelter, 2011; Comeaux, 2015a; Toma, 2003). 


\section{References}

Barrett, F.J. (1996). The organizational construction of hegemonic masculinity: The case of the US Navy. Gender, Work and Organization, 3(3), 129-142. doi:10.1111/ j.1468-0432.1996.tb00054.x

Beilock, S.L., Jellison, W.A., Rydell, R.J., McConnell, A.R., \& Carr, T.H. (2006). On the causal mechanisms of stereotype threat: Can skills that don't rely heavily on working memory still be threatened? Personality and Social Psychology Bulletin, 32, 1059-1071. PubMed doi:10.1177/0146167206288489

Bell, D. (1987). And we will not be saved: The elusive quest for social justice. New York, NY: Basic Books.

Bell, D. (1992). Faces at the bottom of the well: The permanence of racism. New York, NY: Basic Books.

Benson, K. (2000). Constructing academic inadequacy: African American athletes' stories of schooling. The Journal of Higher Education, 71, 223-246. doi:10.2307/2649249

Birrell, S., \& Cole, C.L. (1994). Women, sport and culture. Champaign, IL: Human Kinetics.

Boyle, P., \& Boice, B. (1998). Systematic mentoring for new faculty teachers and graduate teaching assistants. Innovative Higher Education, 22, 157-179. doi:10.1023/A:1025183225886

Bruening, J.E. (2005). Academic stereotypes of African American female student-athletes: A qualitative study. Academic Athletic Journal., 18(1), 22-41.

Bruening, J., Armstrong, K., \& Pastore, D. (2005). Listening to the voices: The experiences of African American female athletes. Research Quarterly for Exercise and Sport, 76(1), 82-100. PubMed

Burgess, R. (1984). In the field: An introduction to field research. Boston, MA: George Allen and Unwin. doi:10.4324/9780203418161

Carrieri, A.D.P., Diniz, A.P.R., Souza, E.M.D., \& Menezes, R.S.S. (2013). Gender and work: representations of femininities and masculinities in the view of women brazilian executives. BAR-Brazilian Administration Review, 10(3), 281-303. doi:10.1590/ S1807-76922013005000002

Chang, M.J., Eagan, M.K., Lin, M.H., \& Hurtado, S. (2011). Considering the impact of racial stigmas and science identity: Persistence among biomedical and behavioral science aspirants. The Journal of Higher Education, 82(5), 564-596. PubMed doi:10.1353/ jhe. 2011.0030

Chang, M.J., Sharkness, J., Hurtado, S., \& Newman, C.B. (2014). What matters in college for retaining aspiring scientists and engineers from underrepresented racial groups. Journal of Research in Science Teaching, 51(5), 555-580. doi:10.1002/tea.21146

Cheryan, S., Plaut, V.C., Davies, P.G., \& Steele, C.M. (2009). Ambient belonging: How stereotypical cues impact gender participation in computer science. Journal of Personality and Social Psychology, 97, 1045-1060. PubMed doi:10.1037/a0016239

Clark, M., \& Parette, P. (2002). Student athletes with learning disabilities: A model for effective supports. College Student Journal, 36(1), 47-61.

Clotfelter, C.T. (2011). Big-time sports in American universities. New York, NY: Cambridge University Press. doi:10.1017/CBO9780511976902

Cole, D., \& Espinoza, A. (2008). Examining the academic success of Latino students in science technology engineering and mathematics (STEM) majors. Journal of College Student Development, 49, 285-300. doi:10.1353/csd.0.0018

Collins, P.H. (1990). Gender, Black feminism, and Black political economy. The Annals of the American Academy of Political and Social Science, 568, 41-53. doi:10.1177/0002716200568001005

Comeaux, E. (2011). Examination of faculty attitudes toward Division I college student athletes. College Student Affairs Journal, 30(1), 75-87. 
Comeaux, E. (2012). Unmasking athlete microaggressions: Division I student-athletes' engagement with members of the campus community. Journal of Intercollegiate Sport, 5(2), 189-198. doi:10.1123/jis.5.2.189

Comeaux, E. (Ed.). (2015a). Introduction to intercollegiate athletics. Baltimore, MD: Johns Hopkins University Press.

Comeaux, E. (Ed.). (2015b). Making the connection: Data-informed practices in academic support centers for college athletes. Charlotte, NC: Information Age Publishing.

Comeaux, E., \& Harrison, C.K. (2011). A conceptual model of academic success for studentathletes. Educational Researcher, 40(5), 235-245. doi:10.3102/0013189X11415260

Connell, R.W. (1982). Class, patriarchy, and Sartre's theory of practice. Theory and Society, 11, 305-320. doi:10.1007/BF00211660

Connell, R.W. (1987). Gender and power: Society, the person and sexual politics. Cambridge, MA: Polity Press.

Connell, R.W. (1995). Masculinities. Berkeley, CA: University of California Press.

Connell, R.W., Ashenden, D.J., Kessler, S., \& Dowsett, G.W. (1982). Making the difference: Schools, families and social division. Sydney, Australia: Allen and Unwin.

Connell, R.W., \& Messerschmidt, J.W. (2005). Hegemonic masculinity rethinking the concept. Gender \& Society, 19(6), 829-859. doi:10.1177/0891243205278639

Constantine, M. G., \& Sue, D. W. (2007). Perceptions of racial microaggressions among Black supervisees in cross-racial dyads. American Psychological Association, 54(2), 142-153.

Corbett, D., \& Johnson, W. (2000). The African American female in collegiate sports: Sexism and racism. In D. Brooks \& R. Althouse (Eds.), Racism in college athletics: The African American athlete's experience (2nd ed., pp. 199-225). Morgantown, WV: Fitness Information Technology.

Crenshaw, K.W. (1991). Mapping the margins: Intersectionality, identity politics, and violence against women of color. Stanford Law Review, 43(6), 1241-1299. doi:10.2307/1229039

Crenshaw, K.W. (1997). Color blindness, history, and the law. In W. Lubiano (Ed.), The house that race built: Black Americans, U.S. terrain (pp. 280-288). New York, NY: Pantheon Books.

Davis, T. (1995). Racism in athletics: Subtle yet persistent. University of Arkansas at Little Rock Law Review, 21(4), 881-900.

Delgado, R. (1984). The imperialist scholar: Reflections on a review of civil rights literature. University of Pennsylvania Law Review, 132, 561-578. doi:10.2307/3311882

Du Bois, W.E.B. (1903). The souls of Black folk. New York, NY: Bantam.

Du Bois, W.E.B. (1935). Black reconstruction. New York, NY: Atheneum.

Eagan, M.K., Hurtado, S., Chang, M.J., Garcia, G.A., Herrera, F.A., \& Garibay, J.C. (2013). Making a difference in science education: The impact of undergraduate research programs. American Educational Research Journal, 50(4), 683-713. PubMed doi:10.3102/0002831213482038

Edwards, H. (1969). (Vol. 69. The revolt of the black athlete. New York, NY: Free Press.

Edwards, H. (1984). The Black "dumb jock": An American sports tragedy. The College Board Review, 131, 13-15.

Engstrom, C., Sedlacek, W., \& McEwen, M. (1995). Faculty attitudes toward male revenue and nonrevenue student-athletes. Journal of College Student Development, 36(6), 217-227.

Espinosa, L. (2011). Pipelines and pathways: Women of color in undergraduate STEM majors and the college experiences that contribute to persistence. Harvard Educational Review, 81(2), 209-241. doi:10.17763/haer.81.2.92315ww157656k3u

Foor, C.E., \& Walden, S.E. (2009). "Imaginary engineering" or "re-imagined engineering": Negotiating gendered identities in the borderland of a college of engineering. NWSA Journal, 21(2), 41-64.

Foschi, M. (2000). Double standards for competence: Theory and research. Annual Review of Sociology, 26, 21-28. doi:10.1146/annurev.soc.26.1.21 
Fountain, J.J., \& Finley, P.S. (2011). Academic clustering: A longitudinal analysis of a Division I football program. Journal of Issues in Intercollegiate Athletics, 4, 24-41 Retrieved from http://csri-jiia.org/documents/puclications/research_articles/2011/ JIIA_2011_4_2_24_41_Academic_Clustering.pdf.

Freeman, A. (1978). Legitimizing racial discrimination through antidiscrimination law: A critical review of Supreme Court doctrine. Minnesota Law Review, 60, 1049-1119.

Gardiner, J.K. (2004). Men, masculinities, and feminist theory. In S. Kimmel, J. Hearn, \& R.W. Connell (Eds.), Handbook of studies on men \& masculinities (pp. 35-50). London: Sage Publications.

Gilligan, C. (1982). In a different voice: psychological theory and women's development. Cambridge: Harvard University Press.

Glaser, B.G., \& Strauss, A.L. (1967). Discovery of grounded theory: Strategies for qualitative research. Chicago, IL: Aldine.

Gurney, G., \& Southall, R.M. (2013, February 14). NCAA reform gone wrong. Inside Higher $E d$. Retrieved from https://www.insidehighered.com/views/2013/02/14/ncaa-academicreform-has-hurt-higher-eds-integrity-essay

Harrison, C.K. (1998). Themes that thread through society: Racism and athletic manifestation in the African American community. Race, Ethnicity and Education, 1(1), 63-74. doi:10.1080/1361332980010105

Herrera, F.A., \& Hurtado, S. (2011). Maintaining initial interests: Developing science, technology, engineering, and mathematics (STEM) career aspirations among underrepresented racial minority students. Paper presented at the Association for Educational Research Annual Meeting, New Orleans, LA. Retrieved from http://www.heri.ucla. edu/nih/downloads/AERA\%202011\%20-\%20Herrera\%20and\%20Hurtado\%20-\%20 Maintaining\%20Initial\%20Interests.pdf

Hurtado, S., Cabrera, N.L., Lin, M.H., Arellano, L., \& Espinosa, L.L. (2009). Diversifying science: Underrepresented student experiences in structured research programs. Research in Higher Education, 50, 189-214. PubMed doi:10.1007/s11162-008-9114-7

Johnson, D., Hallinan, C., \& Westerfield, C. (1999). Picturing success: Photographs and stereotyping in men's collegiate basketball. Journal of Sport Behavior, 22, 45-53.

Johnson, J.J., Bottorff, J.L., Browne, A.J., Sukhdev, G.B., Hilton, A., \& Clarke, H. (2004). Othering and being othered in the context of health care services. Health Communication, 16(2), 253-271. PubMed doi:10.1207/S15327027HC1602_7

Jussim, L., Coleman, L., \& Lerch, L. (1987). The nature of stereotypes: A comparison and integration of three theories. Journal of Personality and Social Psychology, 52, 536-546. doi:10.1037/0022-3514.52.3.536

Kessler, S.J., Ashenden, D.J., Connell, R.W., \& Dowsett, G.W. (1982). Ockers and discomaniacs. Sydney, Australia: Inner City Education Center.

Ladson-Billings, G. (1998). Just what is critical race theory and what's it doing in a nice field like education? International Journal of Qualitative Studies in Education : QSE, 11(1), 7-24. doi:10.1080/095183998236863

Ladson-Billings, G., \& Tate, W. (1995). Toward a critical race theory of education. Teachers College Record, 97, 47-68.

Lapchick, R. (1996). Sport in society: Equal opportunity or business as usual? Thousand Oaks, CA: Sage.

Liberti, R. (1999). We were ladies, we just played ball like boys: African American womanhood and competitive basketball at Bennett College, 1928-1942. Journal of Sport History, 26, 567-584.

Martin, B., Harrison, C.K., Stone, J., \& Lawrence, S. (2010). Athletic voices and academic victories: African American male student-athlete experiences in the Pac-Ten. Journal of Sport and Social Issues, 34(2), 131-153. doi:10.1177/0193723510366541

Matsuda, M.J., Lawrence, C.R., Delgado, R., \& Crenshaw, K. (1993). Words that wound: Critical race theory, assaultive speech, and the first amendment. Boulder, CO: Westview. 
Mavin, S., Bryans, P., \& Waring, T. (2004). Unlearning gender blindness: new directions in management education. Management Decision, 42(3/4), 565-578. doi:10.1108/ 00251740410522287

Maxwell, J.A. (2005). Qualitative research design: An interactive approach. Thousand Oaks, CA: Sage.

Moss-Racusin, C.A., Dovidio, J.F., Brescoll, V.L., Graham, M.J., \& Handelsman, J. (2012). Science faculty's subtle gender biases favor male students. Proceedings of the National Academy of Sciences of the United States of America, 109(41), 16474-16479. PubMed doi:10.1073/pnas.1211286109

National Academy of Sciences, National Academy of Engineering, and Institute of Medicine. (2011). Expanding underrepresented minority participation: America's science and technology talent at the crossroads. Washington, DC: The National Academies Press. Retrieved from http://www.nap.edu/catalog.php?record_id=12984

National College Players Association. (2013). All players united. Retrieved from http://afl. salsalabs.com/o/5889/c/754/p/dia/action3/common/public/?action_KEY=7031

National Science Board. (2015). Revisiting the STEM workforce: A companion to science and engineering indicators 2014 (Publication No. NSB-2015-10). Arlington, VA: National Science Foundation. Retrieved from http://www.nsf.gov/pubs/2015/ nsb201510/nsb201510.pdf

National Science Foundation. (2014). Investing in science, engineering, and education for the nation's future: National Science Foundation strategic plan for 2014-2018. Retrieved from http://www.nsf.gov/pubs/2014/nsf14043/nsf14043.pdf

National Science Foundation \& National Center for Science and Engineering Statistics. (2015). Women, minorities and persons with disabilities in science and engineering (Publication No. NSF 15-311). Arlington, VA: National Science Foundation. Retrieved from http://www.nsf.gov/statistics/2015/nsf15311/nsf15311.pdf

Oriard, M. (2003). King football: Sport and spectacle in the golden age of radio and newsreels, movies and magazines, the weekly and the daily press. Chapel Hill, NC: University of North Carolina Press., 10.1017/S0021875803457046.

Oseguera, L. (2010). Success despite the image: How African American male student-athletes endure their academic journey amidst negative characterizations. Journal for the Study of Sports and Athletes in Education, 4(3), 297-324. doi:10.1179/ssa.2010.4.3.297

Page, M.C., Bailey, L.E., \& Van Delinder, J. (2009). The blue blazer club: Masculine hegemony in science, technology, engineering, and math fields. In Forum on Public Policy Online. Retrieved from http://forumonpublicpolicy.com/summer09/archivesummer09/ page.pdf

Patton, M.Q. (2002). Qualitative research and evaluation methods (3rd ed.). Newbury Park, CA: Sage.

Pierce, C., Carew, J., Pierce-Gonzalez, D., \& Willis, D. (1978). An experiment in racism: TV commercials. In C. Pierce (Ed.), Television and Education (pp. 62-88). Beverly Hills, CA: Sage.

Plummer, K. (2004). Male sexualities. In M.S. Kimmel, J. Hearn, \& R.W. Connell (Eds.), Handbook of studies on men \& masculinities (pp. 178-195). California: Sage Publications.

Sailes, G.A. (1993). An investigation of campus stereotypes: The myth of Black athletic superiority and the dumb jock stereotype. Sociology of Sport Journal, 10, 88-97. doi:10.1123/ssj.10.1.88

Sax, L.J., Kanny, M.A., Jacobs, J.A., Whang, H., Weintraub, D.S., \& Hroch, A. (2016). Understanding the changing dynamics of the gender gap in undergraduate engineering majors: 1971-2011. Research in Higher Education, 57, 570-600. doi:10.1007/ s11162-015-9396-5

Schneider, R.G., Ross, S.R., \& Fisher, M. (2010). Academic clustering and major selection of intercollegiate student-athletes. College Student Journal, 44(1), 64. 
Scott, J.W. (1986). Gender: a useful category of historical analysis. The American Historical Review, 91(5), 1053-1075. doi:10.2307/1864376

Settles, I., Cortina, L., Malley, J., \& Stewart, A. (2006). The climate for women in academic science: The good, the bad, and the changeable. Psychology of Women Quarterly, 30, 47-58. doi:10.1111/j.1471-6402.2006.00261.x

Shenton, A. (2004). Strategies for ensuring trustworthiness in qualitative research projects. Education for Information, 22, 63-75. doi:10.3233/EFI-2004-22201

Simons, H.D., Bosworth, C., Fujita, S., \& Jensen, M. (2007). The athlete stigma in higher education. College Student Journal, 41(2), 251-273.

Simons, H.D., Van Rheenen, D., \& Covington, M.V. (1999). Academic motivation and the student athlete. Journal of College Student Development, 40, 151-161.

Singer, J.N. (2005). Understanding racism through the eyes of African American male student-athletes. Race, Ethnicity and Education, 8(4), 365-386. doi:10.1080/13613320500323963

Smith, W.A., Allen, W.R., \& Danley, L.L. (2007). "Assume the position...you fit the description": Psychosocial experiences and racial battle fatigue among African American male college students. The American Behavioral Scientist, 51(4), 551-578. doi:10.1177/0002764207307742

Solorzano, D.G. (1998). Critical race theory, race and gender microaggressions, and the experience of Chicana and Chicano scholars. International Journal of Qualitative Studies in Education : QSE, 11(1), 121-136. doi:10.1080/095183998236926

Solorzano, D.G., Ceja, M., \& Yosso, T. (2000). Critical race theory, racial microaggressions, and campus racial climate: The experiences of African American college students. The Journal of Negro Education, 69(1), 60-73.

Solorzano, D.G., \& Yosso, T.J. (2001). Maintaining social justice hopes with academic realities: A Freirean approach to critical race/latcrit pedagogy. University of Denver College of Law, 78(4), 23-44.

Steele, C.M. (1992). Race and the schooling of Black Americans. Atlantic Monthly, 69, 68-78.

Steele, C.M. (2010). Whistling Vivaldi: How stereotypes affect us and what we can do. New York, NY: W.W. Norton \& Company.

Steele, C.M., \& Aronson, J. (1995). Stereotype threat and the intellectual test performance of African Americans. Journal of Personality and Social Psychology, 69, 797-811. PubMed doi:10.1037/0022-3514.69.5.797

Stone, J., Lynch, C.I., Sjomeling, M., \& Darley, J.M. (1999). Stereotype threat effects on Black and White athletic performance. Journal of Personality and Social Psychology, 77, 1213-1227. doi:10.1037/0022-3514.77.6.1213

Strauss, A., \& Corbin, J. (1990). Basics of qualitative research: Grounded theory procedures and techniques. Newbury Park, CA: Sage.

Sue, D.W., Capodilupo, C.M., Torino, G.C., Bucceri, J.M., Holder, A.M.B., Nadal, K.L., \& Esquilin, M. (2007). Racial microaggressions in everyday life: Implications for clinical practice. The American Psychologist, 62(4), 271-286. PubMed doi:10.1037/0003066X.62.4.271

Tajfel, H. (1978). Differentiation between social groups. London, England: Academic Press.

Toma, J.D. (2003). Football U.: Spectator sports in the life of the American university. Ann Arbor, MI: University of Michigan Press. doi:10.3998/mpub.16594

Watt, S.K., \& Moore, J.L. (2001). Who are college athletes? New Directions for Student Services, 93, 7-18. doi:10.1002/ss.1

Whisenant, W.A., Pedersen, P.M., \& Obenour, B.L. (2002). Success and gender: Determining the rate of advancement for intercollegiate athletic directors. Sex Roles, 47, 485-491. doi:10.1023/A:1021656628604 